\title{
Formative Assessment: The Malaysian English Language Primary School Teachers' Pedagogical Beliefs and Values
}

\author{
Dr. Stephania Albert Jonglai ${ }^{1}$ ( (D) $\triangle$, Professor Dr. Mark Pike ${ }^{2}$ (D) and Dr. Martin Lamb $\mathbf{8}$ (D) \\ ${ }^{1}$ Phd, Faculty of Education, University of Leeds, West Yorkshire Leeds, United Kingdom \\ ${ }^{2}$ Head of School, Faculty of Education, University of Leeds, West Yorkshire Leeds, United Kingdom \\ ${ }^{3}$ Senior Lecturer, Language Education, Faculty of Education, University of Leeds, West Yorkshire Leeds, United Kingdom \\ $\triangle$ Corresponding Author: Dr. Stephania Albert Jonglai, E-mail: stephaniaalbert76@gmail.com
}

\section{ARTICLE INFORMATION}

Received: March 08, 2021

Accepted: April 15, 2021

Volume: 3

Issue: 4

DOI: 10.32996/ijels.2021.3.4.5

\section{KEYWORDS}

Formative Assessment, Pedagogical Beliefs and Values, classroom observations

\section{ABSTRACT}

This study investigated the beliefs and practices of primary school English language teachers in eastern Malaysia with regards to the country's School-Based Assessment (SBA) reform. The study also investigated the contextual factors affecting the teachers' beliefs and practices, aiming to understand the effects of these beliefs on their practice of SBA in order to extend our understanding of teachers' interpretations of SBA, the challenges influencing these interpretations and thus, what affects the implementation process. After preliminary interviews with seven teachers, the study selected three who had an understanding of and knowledge about SBA and examined their claims to be implementing it. The study conducted classroom observations and then, using post-observation interviews, explored the reasons behind the teachers' practices. The teachers interpreted and implemented SBA using their pedagogical knowledge and beliefs and incorporating existing teaching-learning practices, and they showed awareness of the goals and aims of the SBA initiatives. However, contextual factors affected their implementation process, and thus, their practices deviated from some of the underlying principles and objectives of the SBA policy. The study pointed to a limited uptake of the SBA policy and provided evidence of the importance of studying both the teachers' prior or existing beliefs about assessment and the contextual factors, to understand the motives behind the teachers' actual assessment practices and their attitudes towards assessment reforms.

\section{Introduction}

\subsection{The study of teachers' pedagogical beliefs and values}

The study of teachers' beliefs emerged in the mid-1990s, and since then, there have been many reviews of research into what second language and foreign language teachers think, know and believe about language teaching (Borg, 2006). Literature about teachers' pedagogical beliefs and assessment instructions also gradually emerged at about the same time (e.g. Bleim and Davinroy, 1997). Spillane et al. (2002) and a number of other researchers suggested that teachers' pedagogical beliefs can shape what they actually do (e.g. Stipek et al., 2001; Kuzborska, 2011), because people have their own sets of ideas which help them determine how they should understand their experiences and how they should value certain educational goals (Pring, 2004). Belief is also often described as a lens through which one looks when interpreting the world (Philipp, 2007). Similarly, other studies have shown the importance of values to teaching (e.g. Clark and Peterson, 1984; Pajares, 1992).

A number of studies have also identified differences between beliefs and values. For example, Bishop et al. (2003) found beliefs to be associated with true/false dichotomies, whereas values are associated with desirable/undesirable dichotomies. To further distinguish between beliefs and values, researchers such as Rokeach (1973, cited in Philipp, 2007) viewed values as enduring beliefs, while Clarkson and Bishop (1999) viewed values as beliefs in action. Bishop et al. (2003) contended that values influence, rather than determine, the choice of possible actions available. Bishop and his colleagues also pointed out that the similarities

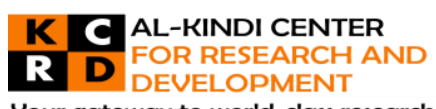

Your gateway to world-class research

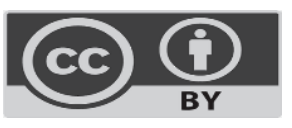

Published by Al-Kindi Center for Research and Development. Copyright (c) the author(s). This open access article is distributed under a Creative Commons Attribution (CC-BY) 4.0 license 
between beliefs and values are far greater than the differences, because as people hold incompatible values, so too, they hold beliefs which may conflict. Bishop et al. further contended that for this reason, mathematics educators usually use the terms 'beliefs' and 'values' interchangeably. Based on these discussions, in this study I will also use the terms interchangeably.

The term 'beliefs' has also been defined with respect to terms such as 'attitude and orientation' (Eisenhart et al, 1988; Richardson, 1996), 'attitude and knowledge' (Davis and Andrzejewski, 2009) or 'individual cognition' and 'cognition' (Spillane et al, 2002; Borg 2006). In English language teaching, Borg (2001) defined a belief as a proposition which is consciously held by the teacher, perceived as true by the individual and filled with motives and positive intentions which help guide his or her thinking and actions. Zheng (2009, p. 74) defined a belief as 'inclusively to embrace the complexity of teachers' mental lives underlying their practices'. On the other hand, Halstead and Pike (2006, p. 24) define values as,

principles and fundamental conviction which act as justifications for activity in the public domain and as general guide to private behaviour, they enduring beliefs about what is worthwhile, ideals for which people strive and broad standards by which particular practices are judged to be good, right, desirable or worthy of respect.

This means that a study of teachers' pedagogical beliefs or values form part of the process of understanding how teachers conceptualise and approach their work. I will use Halstead and Pike's above definition about pedagogical values in this study.

Richardson (1996, p. 105) outlined three sources which help to shape teachers' pedagogical beliefs:

- Personal experiences, in which teachers may be influenced by what they have previously learned and observed from a particular individual and which may inspire or shape their own teaching (e.g. social encounters, teacher preparation, professional development etc.);

- Experience with schooling and formal knowledge, beliefs that teachers are influenced by their experiences as learners and the degree to which the community has agreed certain teaching or learning to be worthwhile and valid (i.e. models of teaching, classroom management and classroom environment) and;

- Enculturation, which 'involves incidental learning process individuals undergo throughout their lives assimilating the cultural elements present in their personal world' (Pajares, 1992). In other words, 'education is directed and purposeful learning, either formal or informal that has its main task in bringing behaviour in line with cultural requirements' (p. 316).

Hence, teachers' pedagogical beliefs are considered to be a great influence on their underlying practices. Kagan (1992) contended that their beliefs are also relatively stable and resistant to change. For example, Rahman (2014) examined the dissemination of the Malaysian primary school English language curriculum reform which aimed and 'focused on the development of students ability in using language appropriately, meaningfully and effectively' ( $p .169)$. Among her participants were teachers, district officers and a curriculum developer. Adopting a mixed method strategy of interviews and classroom observations, her study highlighted the fact that the teachers continued to believe that learning provides 'fact and information' and believed that effective teaching is where students should remember what has been taught. The reason behind her findings was that teachers had not fully understood the content of the curriculum. This indicates that if teachers do not believe in the value of the stated change and what they can bring to their teaching, the change is unlikely to take effect.

In Spillane's framework, the individual cognition element recognises that the development of new knowledge occurs through existing structures (e.g. teachers' existing knowledge and practices concerning teaching and learning). Spillane emphasised that these structures need to be supported, or little may be achieved in terms of realising change. Harvey (1999) investigated teachers' implementation of a new model of teaching science in South African primary schools and identified the fact that the teachers' commitment to change was not very strong and that they had returned to their pre-existing practices because support was not provided during the change. This suggests that teachers should be given time to conceptualise both their practices and what the stated change actually means for them.

Some suggest that teachers need to modify their beliefs to accept new teaching and learning methods (Zeng, 2005, cited in Wedell, 2009). Zhang and Liu (2014) also said that teachers need to incorporate reform ideas into their beliefs systems. However, research has shown that teachers' pedagogical beliefs are difficult to change (e.g. Kagan, 1992; Pajares, 1992; Raths, 2001; et al., 2012; Xu, 2012; Mihaela, 2015). Fullan (2001) warned that readjusting one's beliefs is not easy, as it involves 'the core value held by individuals regarding the purpose of education' (p. 44), and suggested that to alter teachers' pedagogical beliefs, extensive support must be provided. Similarly, Nunan (2004) emphasised that since the choices teachers make about what they do in their classrooms are 'underpinned by beliefs about the nature of language, the nature of the learning process and the nature of the teaching act' (p. 6), it is important to ask teachers what they think about new educational reforms. Such information may provide 
a window into their beliefs and understanding concerning effective pedagogy. This new insight might then lead to strategies for conducting effective implementation. This also indicates the importance of identifying which prior pedagogical beliefs or values may challenge or have an impact on teachers' interpretations of a new curriculum policy.

A growing body of research argues that teachers' pedagogical beliefs and practices should be studied within the sociocultural contexts of their work because the relationship between their beliefs and practices is both complex and context-dependent' (Mansour, 2013, p. 1). The following section discusses this.

\section{Characteristic of the Malaysian English language assessment and it's challenges}

It is widely recognised that sociocultural context or setting plays a significant role in the way teachers conduct their teaching (Tudor, 2001; Orafi, 2008; Wedell, 2009). This affects what teachers and students believe to be the norms in the ways a lesson should be taught, learned and assessed in that particular setting.

The Malaysian primary schools are divided into two types, the national primary school (SK) is attended by the Malays in the west coast of Malaysia and by the 'bumiputras' or 'sons of soil' (the indigenous people in the east coast of Malaysia). The Tamil-type primary school (SJKT stands for Sekolah Jenis Kebangsaan Tamil in the Malay language) (only in the west coast of peninsular Malaysia) is attended by Indians, whereas the SJKC is attended by the Chinese. The language medium of instruction in SK is the Malay language, whereas it is Telugu in SJKT and Mandarin in SJKC. However, the English language curriculum (as one of the compulsory curriculum in the Malaysian primary school) expects the teachers to teach using the English language entirely in their teaching and learning. Listening to the teacher modeling the spoken language is hoped to develop learners' interest in articulating and learning the English language. Nevertheless, it is not always possible for teachers to carry out their teaching using the English language throughout their entire lesson. Most commonly, teachers will use a mixture of English and Malay or will teach in the language of instruction which their schools are using. Translating the English language into the Malay language or into the students' mother tongue (the language in which the pupils were brought up with at home by their parents other than the Malay language) is also a common practice in the Malaysian English language teaching context. The teachers' teaching is also influenced by the English language backgrounds of the students. More English language is used when the students have a good English language background (pupil with knowledge of the English language learnt from home taught or exposed by their parents) and a mixture or language translation if they have less or none. The teachers' pedagogy is also influenced by their own English language competence and proficiency. Therefore, the use of English for teaching and learning and how much the language is to be used in the lesson depends on the capability of the teachers and the students themselves. To make a particular task understandable and clear, the teachers tend to use the language which both the teachers and students feel most comfortable with and which is most convenient. In this case, the Malay language is often used to teach the English language and to give a clear explanation of the assessment to be conducted later on.

The lower primary (Level One) consists of Year One to Year Three (pupils age from 7-9) and the upper primary (Level Two) consists of Year Four to Six (pupils age from 10-12). The actual teaching of English language subject starts from Year One. Therefore, pupils in Year One will only experience formal teaching and learning of the English language subject during this time in which they are taught the four English language skills namely listening, speaking, reading and writing as discussed earlier by trained English language teachers. This means that the pupils are not yet used to the type of assessment that I am investigating in this study. This potentially lays down a challenge for teachers of younger age groups in providing feedback for learners, an issue which I am also investigating in this project.

In terms of class size, it is normal for Malaysian primary school teachers to have thirty to forty (sometimes more) pupils in a classroom. Usually these classrooms were built only to accommodate fewer than thirty pupils. In dealing with large class sizes, pupils in each schools are usually screened and placed in different classes according to their abilities or according to their literacy and numeracy performance (that is if there are extra classrooms available in the school). In addition, Malaysian English language teachers usually teach more than one class daily (sometimes 3 or 4 group of classes in different years or levels). Additionally, most primary school classroom in Malaysia are built with either wood or concrete walls and floors (in a rectangular shape classroom). The windows in the classrooms (the right and left side view) take up most of the walls which means that wider windows are built and with two exit doors to make ventilation system more effective for the Malaysian hot climate weather (fans and lights are supplied in each classrooms; the numbers of fans depends on how large the classrooms are). Therefore, the acoustic environment is challenging- Malaysian primary school teachers may not hear their pupils clearly and may hear noise from other classrooms.

Furthermore, the introduction of the new English language KSSR curriculum in 2011 also introduces some extra periods of English language teaching in primary school, from 7 periods (Level 1) and 8 periods (Level 2) to 10 teaching periods in a week; each period takes about 30 minutes per lesson). The assumption of the additional time period is that the more time the teachers spend with the pupils, the better they will perform in the English language. The class size, the physical condition of the 
classrooms and the number of lessons and classes to be taught could be an extra workload for some teachers and may limit the extent to which they can work effectively with SBA in this study.

The Malaysian SBA encourages the teachers to regularly give homework and worksheets. In the Malaysian primary school classroom the practice of giving homework and worksheets is quite common. The teachers are used to giving out tasks at the end of their teaching and learning in order to determine whether the lesson they have taught was successful and was clearly understood by the learners.

However, the consistent daily recording of students' individual progress and their performance in given tasks is not a usual practice for teachers in the English language classroom. Nor does the usual practice include providing useful and constructive feedback to the learners. The most important thing for both teachers and students after each successful task is assessed is the number of correct answers provided by the learners. For the teachers, this simply shows that another lesson has been successfully taught and learned, and they can proceed to another level, unit or topic of a particular lesson.

In terms of assessment, Malaysian primary school teachers and students are used to doing paper and pen tests. This means that an assessment is officially conducted when it involves filling out and answering questions on a piece of paper. Therefore, making observations and preparing checklists or using other instruments to monitor a learner's progress while he/she accomplishes a certain task (e.g. classroom presentation, choral reading or reading individually, doing group work, pair working, making puppets) has not been a common practice in the teachers' understanding of assessment.

Malaysian English language teachers are also used to conducting a summative assessment two or three times a year, checking and recording it as a one-off report for the students and parents and for a record for the schools (in the form of letter grades). Teachers will only conduct formative assessments (in the form of monthly tests as understood by them) if there is a necessity to do so, and these are usually used for drilling and preparing the students for standardised examination. Whether dealing with formative or summative assessments, the teachers consider them both basically as means used to measure the ability and competence of the students in answering questions and to prepare individual learners for national standardised examinations. The factors above could give some information that SBA might face have some complications and challenges in its implementation in the Malaysian primary school classroom.

The situation and factors stated above could also reflect in the way the Malaysian primary school teachers conceive and understand about formative assessment. Thus, they might implement formative assessment or assessment for learning without having a clear understanding of what they actually meant to do. This paper is part of an investigation from my thesis study which explored the teachers' beliefs and practices of the Malaysian formative assessment of a small group of teachers in Eastern Malaysia.

\section{The principles and misconceptions of formative assessment}

Christodoulou (2014) argues that in some contexts formative assessment is introduced without considering the importance of providing clear feedback to students on their learning progress. She stated the importance of guiding students in their learning because according to her 'new information without proper guidance does not lead to effective learning but instead leads to confusion, frustration and misconceptions' (p. 39). Black (2004) states that teachers often consider that giving a test every week and telling the students their achievements to be formative assessment. This demonstrates the misinterpretation in which any ongoing or frequent assessment (e.g. oral presentations, portfolios etc.) is defined as formative (Heritage, 2010). Heritage also found that some teachers tend to regard formative assessment as a particular kind of measurement instrument.

In England for instance formative assessment was perceived well by teachers, educationists and the government. Every school and teachers in its country has implemented it, well supported government training, since the concept was introduced by Black and Wiliam in 1998. However, its implementation process has not run as expected. Even though teachers in the country (in England) had followed Wiliam and Black's (1998) advice to replace grades with comments, they still tend to treat assessment for learning as high-stakes. This is because in its Ofsted system schools are not only judged by how well their pupils perform in their terminal exams (SATs and GCSEs) but also their performance from the most recent teacher assessments (Christodoulou, 2016).

Therefore, there is clearly a great deal of pressure on these sets of data. Schools might want to set up internal assessment systems that aim to diagnose weakness, but the fact that the data in the systems will be used by Ofsted to judge a school will make that much less likely (Christodoulou, 2016, p. 22).

One possible reason identified was that the word 'assessment' could have been misunderstood; 'when government get their hands on anything involving the word 'assessment', they want it to be about high-stakes monitoring and tracking, not low-stakes diagnostics' (Christodoulou, 2016, p. 21). As Christodoulou elaborates; 
Wiliam has said he wished he had called AfL 'responsive teaching', rather than using the word assessment. He has also said that, "The problem is that the government told schools that it was all about monitoring pupils' progress; it wasn't about pupils becoming owners of their own learning. AfL is not just about teachers being responsive; it is about pupils responding to information about their progress".

The Malaysian SBA document also stated extensively that SBA is an assessment that is conducted to monitor its pupils' growth, progress and provide constructive feedback, not about pupils becoming owners of their own learning, as far as I could see from my own reading. This could influence how the Malaysian teachers understand and use the term 'formative assessment' in this study.

Although feedback is an important element in formative assessment, Black and Wiliam also warn against the challenges which may be faced with feedback. The challenge for a teacher is to gain insight into the students' way of thinking about the subject matter at hand and to frame feedback which helps them move towards specific learning goals. Research has demonstrated some of the challenges associated with feedback. For example, Gibbs and Simpson (2004) claim that the quantity of feedback offered to students in UK higher education has declined due to large class sizes, although they have no evidence for this claim.

In a study specifically about feedback, Hounsell (1987) found that the feedback students received from their lecturers was either not read or was thrown away. These actions were closely associated with the grades accompanying the feedback; if the grades were low, it was unlikely that students would read the comments provided (Wotjas, 1998). Therefore, when the emphasis is on grades or marks, this might indicate a judgement only about the individual level of achievement, and it might decrease students' self-efficacy (Wotjas, 1998). Thus, it is suggested that formative assessment feedback should be descriptive in nature. In another study, Maclellen (2001) found that higher education students claimed feedback never helped them understand things, and feedback did not prompt discussion.

However, in a primary school context, Sardereh and Saad (2012) discovered that the school students acknowledged the receipt of formative or descriptive feedback from their teachers. These students also claimed to like receiving feedback on their work. Nevertheless, they reported that they did not know how to use the feedback given by their teachers. Duncan (2007) stated that it is possible that students may not pay attention to feedback. This might be because according to Spiller (2009) the student might not make sense of the feedback given to them or they do not understand the purpose of the feedback process.

Sadler (1989) states that in order for feedback to be effective, students should have a complete understanding of learning targets and success criteria, and they also need to understand where they are, relative to the targets and criteria, and how they can close the gap. This condition requires the students to actively engage with feedback:

Students should be trained in how to interpret feedback, how to make connections between the feedback and the characteristics of the work they produce and how they can improve their work in the future. It cannot simply be assumed that when students are 'given feedback' they will know what to do with it (p. 4).

In other words, formative or descriptive feedback should provide students with information on how they can improve their learning. Spiller (2009) also suggests that careful 'preparation beforehand can help to prime the students about the nature of feedback and its role in the learning process' (p. 4).

However, Fook and Sidhu (2013) noted that Malaysian secondary teachers were aware that classroom assessment was to be an ongoing process and felt that learning was more meaningful when a student could obtain immediate feedback. However, some teachers said that time constraints, the rush to complete the syllabus, a heavy teaching load and administrative duties hindered them from using SBA results to enhance student learning. Similarly, Barley (2013) found that despite teachers' positive views of the Hong Kong SBA, an overwhelming workload caused them to make limited used of feedback. So the challenges of implementing SBA hindered the teachers from providing useful and meaningful feedback. It is possible the teachers in this study will face similar difficulties (i.e. student not reading feedback provided or having trouble understanding the feedback given to them, time constraints etc.) as discussed and described in the studies of literature above.

\section{Methodology}

An evaluative-interpretive research stance is thought to be the most suitable methodology for approaching the topic. According to Richards (2003), it is important that the researcher understands the theoretical assumption of his or her research paradigm, for failure to do so will entail serious consequences for the whole enquiry. 
The interpretive approach aims to advance knowledge by describing and interpreting the phenomena of the world in order to share obtained meaning with others (Bassey, 1999). Walsham (1993) argues that there are no 'correct' or 'incorrect' theories in the interpretive tradition; they should merely be judged on how 'interesting' they are to the researcher and to others working in the same field. Similarly, Willis (1995) argues that there is no single correct route to, or particular method of acquiring, knowledge. According to Aikenhead (1997), the interpretive paradigm is underpinned by observation and interpretation; to observe is to collect information on an event, while to interpret is to draw meaning from that information. This places emphasis and value on the human and interpretative aspects of learning about the social world and the significance of the investigator's own interpretations and understanding of the phenomenon under study (Snape and Spencer, 2003).

My study has benefitted from the interpretive research paradigm in the following ways:

- It gave me the opportunity to work with people in their normal setting.

- It offered me the flexibility of using different methods to understand the phenomenon being investigated.

- It allowed me to establish and develop relationships with the participants in the study.

- It enhanced my understanding of the participants' reasoning behind their actions

In this article, three case studies were selected. I explored their knowledge about SBA and examined their practices.

\subsection{Data analysis}

2.1.1 The summarization technique

One of the way to understand my data, I employed a summarisation technique. Summarizing gives a brief statement of the main points of (something), in other words, it's a technique that helps to condense, outline, recap and review of (something). It's a technique that helps to understand the basic ideas behind the piles of data or information collected from the fieldwork. Bogdan and Biklen (2007) state that summarizing can help to move the interpretation of the data. Specifically, working 'on writing a clear paragraph summarizing what it is you want to tell the readers' (p. 197) will help the writer's interpretation of the data more clearer and provide basic assumption of what all the data means to the writer. As data analysis is a process of making sense out of the data and to make sense out of the data involves consolidating, reducing and interpreting what people have said and what the researcher has seen and read (Merriam, 2009, p.176). To me, summarizing is a process that helped me to review, gave a preliminary interpretation and basic assumption of the data generated from the interview. Because data analysis is a complex process (involves moving back and forth between bits of data), and summarization helped me in identifying and locating which set or part of the data is giving me basic ideas in forming categories, themes and some ideas the answer to my research question(s). For instance, one purpose of this study (also one of my research questions) is to identify teachers' interpretation of SBA in terms of their knowledge and pedagogical beliefs about SBA. To know this after each interview I started transcribing immediately (this allows me to reflect and summarize the whole interview more clearer). From the summary, I outlined which sentence says about teachers' knowledge and pedagogical beliefs about SBA and then I move back to the interview data to find quotations to provide evidence to these findings. I also referred to my notes (field notes) as additional evidence for the findings and to further assist me with the summaries. It was a starting point for me to portray and tell the story of my participants.

\subsection{The participants' stories}

\subsubsection{Beliefs about formative assessment}

Before I proceed, I should state that I am well aware of the possible criticism of this type of research, where the data elicited may not constitute the 'teachers' principled rationales but rather post hoc rationalisation (i.e. explanation constructed retrospectively)' (Orafi and Borg, 2009, p. 250). However, I am confident that the teachers I interviewed and observed from different schools articulated their beliefs honestly and presented similarly honest accounts of their experiences, for the following reasons. I began with a preliminary interview with each teacher, followed by a one-month spent in each school, observing and interviewing other teachers and being involved in the school's activities, besides conducting classroom observations and post-observation interviews. After the data were put into themes, I returned to the teachers a year later to share and validate my findings and to allow the teachers to explain further their own beliefs and actions regarding SBA. I applied a member-checking 'dialogic approach', as suggested by Harvey (2014). Harvey explains that a 'dialogic approach' goes beyond the method described (in Lincoln and Guba) and involves the participants further in the research process through a series of dialogues, thus providing rigour and trustworthiness for the study itself. 


\subsubsection{Liz Story}

Liz assesses her pupils by giving many conventional types of worksheets (e.g. matching sentences to pictures, mostly filling in the gap) to the students, one worksheet after another. Her teaching method is somehow conventional too (repetition, memorisation, drilling).

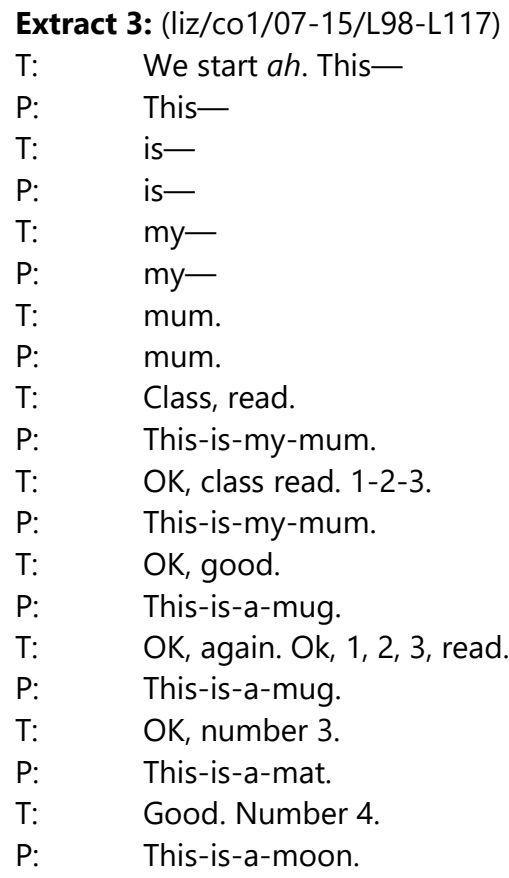

The way she conducts her lessons without group work and focusing on the teacher-to-student approach indicates her traditional and conventional preference of teaching and assessment. When I asked whether she conducted repetition, drilling and revision activities with her new classroom, she answered that she did, but later, she noticed that they got bored with the activity, so she needed to create a variety of activities to get her learners interested in learning the English language. This also meant that Liz would give different set of assessments to each different group of learners. This means that she provides individualized assessment for the group which she identifies that pick up quickly in the lesson and another different set of questions to those who does not:

I give different sets of assessment for these few groups of pupils. In my previous class, they get all the same papers. I tried the same before, giving them the same assessment, but the good ones turn up to finish early, and they get bored, probably because the worksheet was too easy for them. When I added a few more sentences for them to rearrange without teaching, they couldn't do it. They also need a bit of guidance. (liz/pv/08-16/L43-L49)

4.2.1.2 Chen's story

Chen likes giving her learners the opportunity to learn in other ways besides the conventional method of teaching and assessment. Chen's SBA practices seem to be more personalised in terms of her approach to guiding and facilitating her learners. This is also evident in the way she teaches reading, using colourful and decorative templates for her learners' writing activities, making them do a presentation of their work to the whole class and incorporating technology into her writing assessments. Chen also strongly believes that learners should not be tested until they are ready to be tested (e.g. she taught the content of the Linus test before giving the test for her students to do), and in her view, the effort that the students are putting forth into the tasks they do should be considered enough pupils and for her to know about her learners' progress. In Chen's assessment practices, she continues to guide (prompting, giving ideas what to write), give feedback and monitor her learners while they are doing their tasks. The following excerpt shows an example of how Chen conducted her assessment activity:

Extract 1: (chen/co1/08-15/L543-L570)

$\mathrm{T}$ : $\quad$ OK, now you have described these four characters that you think are most interesting from this book. Now, what I want you to do is your favourite character. You are going to name my favourite character from the book is Jules, Jules' new teacher, Anastasia, Mr. Gelatti. You are going to say, I like Jules, Jules' new teacher, 
Later, after that:

Anastasia or Mr. Gelatti, why, because? You can use all those words that you have learned earlier to describe all these characters. Can you do it now? (The teacher looking at her watch). At 8,1 will be going to collect this, OK. (The teacher distributes her template for the next tasks). OK think of who you are going to choose? Choose one character. One character. (The pupils are completing the tasks)

Chen walks around to look at how the pupils are doing. A pupil came to ask. Chen says,

T: $\quad$ My favourite character is...? You can even write about the character that is not described earlier. Maybe you like 'Yuv', because you think she is pretty and you like Japanese. You can even write about 'mum'. You can even write about 'grandma', but the reasons are all up to you. You can use the words that I have provided there, that I have written down and we have discussed earlier. Or you can add on your own idea. You can add sendiri (yourself).

While students are doing the task, the teacher pastes the previous work on the pupils' corner on the right-hand side of the class. Then she starts going around the class again. A pupil shows her work to her. The teacher takes a look. Chen explains;

Why is she being a good teacher? Kenapa dia cikgu yang bagus? (Why she is a good teacher?) You think that she is a good teacher? Explain more, and then why do you think she is magical?

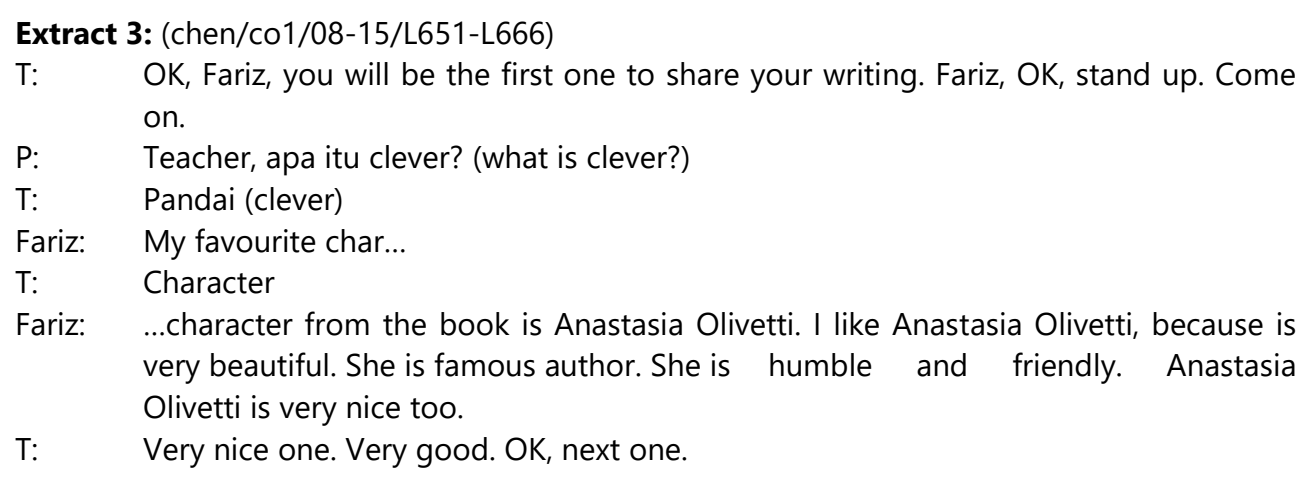

I conducted a post-classroom observation interview with Chen in order to understand the reasons behind her actions. The first thing I noticed about Chen's assessment practice was her use of colourful and decorative templates, so I asked why she used these when her students did the writing activities:

So they feel that they are not doing assessment. The pupils don't feel threaten by the assessment term hanging over their head. (chen/I1/07-15/L245-L250)

Her action is also influenced by a belief about how the students will respond to the way she presents the activity:

So I tried to put activity in a way so that they are feeling like they are just doing like any other task that they do, that they have done. (chen/I2/08-15/L82-L83)

Another aspect that I noticed during the writing assessment was that Chen used teacher-talking time to give prompts or guiding questions. She believed that these would provide her learners with ideas about what to write in the assessment activity she had given to them. When I asked Chen why guiding the learners was so important to her, she said:

Because for most of the curriculum for SJK is under 'with guidance', it's the catch 'with guidance' at the description, so I would sometimes be more open to giving them guidance. In terms of giving some words they don't know how to spell, maybe words that they know in Malay their own language but they don't know how to translate it in English. (chen/l2/0815/L98-L 102) 
Chen went on to say that the purpose of assessment is the following:

Do not let the students feel the pressure of having the assessment on their head. So, you really need to really play the role. Basically, you can do it like I did, or maybe be more rigid, don't give them any guidance at all, but I would prefer to give them guidance along the way. They just write and answer on their own. (chen/I2/08-15/L89-L93)

\subsubsection{Dennis story}

Dennis used some language translation to get the meaning of his activity across during the explanation of his assessment. He conducts memorisation activity to get his students to remember the word list which they have learned. He makes use of a taskbased approach to do his group work activities and to scaffold his students' understanding of the story before he conducts his real assessment. He uses games in preparing them for the reading comprehension and the assessment and throughout his lesson (e.g. his technique of introducing new words in a playful manner). The extract below shows how he did this as well as the instructions he gave his learners during the assessment:

Extract: (den/co1/10-15/L626-L653)

$\mathrm{T}$ :

P:

A pupil:

$\mathrm{T}$ :

P:

$\mathrm{T}$ :

$\mathrm{T}:$

A pupil:

$\mathrm{T}$ :
OK, now I want you to keep the picture. OK, sit down everybody, now this one is an individual work. ok buat kerja sendiri tidak boleh meniru (do it yourself, and you can't copy) OK so, you can refer to the work earlier. OK, hello, you have a new friend (a new pupil walks into the class)

Hello!

What's your name? (a pupil asking the new student for her name)

OK, you can sit there welcome. OK now, uh...duduk semula di tempat biasa jangan duduk dalam kumpulan (sit at your own place not in group) OK, you can go back to your seat. OK, now, so you look at the question. Read the following statements; if the statement is correct, you put a tick in the box provided; if the statement is false, you put a cross. Listen! OK dengar sini (listen) kamu tanda betul atau salah (mark true or false), you read all the statements there, for example number 1 . The story begins early in the morning. Is it true or false.

False

The statement is false, because the story begins at midnight? Midnightkan (right)? Not early in the morning. So it's wrong, so bagi tanda cross, pangkah. (make a cross) Alright, number 2-9 you do it yourself. If you don't understand, you ask me, OK? Escape means "melarikan diri" (then the students started to do their work; while [they were] doing so, Dennis said the following)

OK you answer all the questions. Siapkan besok hantar (finish it and hand in tomorrow) siapa yang sudah siap boleh hantar sekarang (those who have finish can hand in). If you have completed you can submit. OK, come on, we have 1 more minute (some students have completed and hand in their work to Dennis) so, the rest of you can send to me tomorrow.

kalau tidak siap hantar kah? (if not finish can we hand in?)

No, tomorrow. The pictures you can keep. Yes, it's for you. Anyone else?

In order to understand the reasons behind Dennis's assessment practices, I also conducted a post-classroom observation interview with him. During my observation with Dennis, he used worksheets as part of his teaching strategy and assessment. He said that it was important to re-evaluate his approaches in the classroom, and the worksheets helped him to do this. He thinks the pupils' results from the worksheet show him which part of his lessons need adjustments. He will re-do a whole lesson and the assessment if he finds out that his learners are not doing well in the task he gives:

When I gave them the worksheets it's actually more for me. It is actually more to really evaluate the effectiveness of my teaching. Yes, because I want to check whether uhm ... what I did in the classroom really help the student understand the story, actually. So, I haven't really checked their worksheets but maybe once I found out that, OK, for example, my students could not able to answer as well as desired. I would re-evaluate my lesson. I would evaluate my approach. (den/I2/10-15/L77-L83) 
To Dennis, the purpose of assessment is not only to verify learners' learning achievements but also to verify how the teachers are doing with their teaching. He said they would be able to make adjustments and modifications to their teaching and assessment approaches on the basis on what they find out.

\section{Summary of the three case studies}

The teachers in this study showed that they had some knowledge and strong beliefs about the Malaysian primary school formative assessment, based on the evidence gathered in the preliminary interviews I conducted with them. These teachers also dealt with the assessment in their own unique ways, with their own sets of beliefs, which might have been influenced by the number of years of their teaching experiences and the kind of training that they had with the SBA. For example, Liz had been teaching for twenty-four years and so she might be more accustomed to and influenced by the traditional method of teachingassessment in which pupils should listen and repeat after the teacher, memorize new language, group work should be avoided for fear that the activity would disrupt her lesson.

By contrast, Dennis had only been teaching for ten years and had been trained more recently. Therefore, although he believes that assessment involves memorization, he believed that memorization should be conducted in a fun and interesting way. It is possible that this is because his teacher training experiences could have exposed to him to a variety of activities that are more fun and engaging, or emphasised the need to entertain learners as well as educate them.

The teachers' SBA practices may also differ with regard to how recently they have undergone their SBA training. For instance, Liz had her SBA training when it was first introduced in 2011 and Dennis in 2012. Since SBA is still new, the trainers might have not covered some details that the teachers should have been aware of (e.g. the importance of feedback in formative assessment). The teachers had less exposure to what formative assessment really is. By contrast, Chen had her assessment training four years after Liz (in 2014) in which she was also the district English language Year Four KSSR trainer. This meant that Chen had first-hand exposure to SBA and the English language KSSR curriculum during her training. The trainers who trained her might have had more exposure to what SBA is and might have learnt something from the past courses. Therefore, she showed confidence in her SBA practices involving more hints, pointers and prompting for her pupils during their assessment. She also created more group work activities and employed a variety of colourful assessment materials.

Additionally, the teachers' practices may have been influenced by other factors such as class size, the streaming of the classes or the physical condition of the classrooms. For example Liz's Year One classroom consisted of a group of pupils who had problems with their numeracy and literacy and it also had the most number of pupils compared to the other Year One classrooms. According to Liz, her class often misbehaved. This was also the reason Liz would not conduct any group work for her class. Therefore, she preferred using activities that she thinks could control the behaviour of her pupils- for instance she distributes one worksheet after another so she could attend to other pupils. Even so, as shown in Liz's portrayal above, one of her pupil had boldly walked towards me asking what I was doing while Liz was still teaching and attending to them. Chen in the other hand, had fewer number of pupils (less than twenty pupils) in her Year Five classroom. Her pupils were also aged between ten to eleven years old. Therefore, she used group work activities more often as part of her assessment because they were more able to respond to instructions given to them. Although Dennis is teaching a Year Two classroom (age 8), he may prefer using group work prior to his assessment because according to Dennis the class he was teaching were streamed and they are good performing pupils compared to the rest of the Year Two classrooms in his school. The class were also able to response to instruction given to them.

However, the teachers in the study as stated earlier also held common beliefs and engaged in common practices, for example, trying to integrate the strategies recommended in the SBA document with the traditional methods as a way of dealing with the SBA practices and other priorities. I also noticed in the teachers' responses and with my classroom observations with them that the teachers' guidance is associated with feedback (through hints, prompting etc.) and the results of the assessment had helped them to alter and modify their teaching-learning strategies in the classroom according to the learners' needs and their pupils' proficiency level. However, the teachers had not said about how the pupils responded to the feedback and if the pupils were able to move forward in their learning with the feedback. This is because the teachers might think that formative assessment is all about teachers changing and improving their lesson, motivating learners to learn the English language, giving the learners the kind of lesson they need but not about learners getting to respond to the feedback and how their respond to the feedback could improve their learning. For example, when I asked Dennis about what the assessment result helped him with, he said that it helped him to find ways to improve his teaching and find the activities that are more fun and engaging for his learners. 
The teachers' common beliefs:

1. Assessment as a process for learning: It is clear to them that assessment involves more than just testing. For them, assessment is a natural process which takes into account not just the product but the whole process, such as the students' attitudes, the students' progress and also their effort in completing the tasks given to them.

2. Teaching and assessment are inseparable: Assessment provides an intrinsic motivation for the teachers to develop and improve on their own teaching. It tells them where and what to change in their approaches. It gives them the opportunity to make adjustments to teaching and assessment practices and to become familiar with other possible methods of teaching and assessment. Dennis, for example, says he cannot imagine teaching without assessment.

3. Memorisation and repetition drills: It was noticed, through the teachers' responses, that Liz and Dennis believe in the efficacy of this method to construct meanings of the words, phrases and sentences used in the lesson. Most activities assigned were related to drilling in vocabulary and sentences and to translating from English to Malay and vice versa. The teachers also mentioned that they used the memorising of vocabulary, phrases and sentences as well as repetition during reading and writing activities. They said that this was to enable the learners to recall the language already taught when they were assessed later.

4. The integration of interactive learning: In the effort to change what is done in the classroom with respect to assessment, the teachers in this study have tried to incorporate games, dynamics, role play and presentations (e.g. Dennis). This strategy is thought to encourage students' participation in the lesson, and participation means involvement. In contrast, Liz tries to avoid such activities as to her it will disrupt her lesson.

5. Worksheet-based assessment: The use of worksheets was one of the teachers' most popular choices of teaching strategies employed in the classrooms to ensure assessment had taken place. Worksheets provide an opportunity for the teachers to make links between what is learned and where to take the learners in the next level of the lesson. The teachers in this study assessed their students' learning as they worked in the classroom and did not just collect the worksheets at the end of their lessons. The teachers walked around the classroom and stopped at particular individuals and offered the guidance they needed. The teachers even used prompting strategies to give ideas and guidance in the students' writing tasks.

\section{Discussion}

Based on the above discussion, this study showed that teachers' pedagogical beliefs were the most influenced factor that contributed the way the teachers' implemented SBA. This was evident in the way they adapted SBA into their classrooms (e.g. the beliefs in giving guidance throughout assessment activities, scaffolding so learners could operate in their ZPD, associating guidance with feedback).

However, the teachers' existing pedagogical beliefs toward teaching, learning and assessment represented the challenges for implementing some of the recommended Malaysian primary school SBA. For example, the teachers in this study believe assessment involves the ability to memorise what is learnt where they apply teaching strategies such as drilling and repetition of words, phrases and sentence structures prior to the assessment. However, the introduction of SBA suggested a number of teaching activities to lessen Malaysian teachers rote teaching and learning (see, Appendix A). In another example, the Malaysian SBA also introduced variety of ways for the teachers to assess their pupils' performances. The three teachers in this study (including the four teachers) preferred and believed that worksheets were the way they should assessed their pupils. In addition, the introduction of SBA was also to create a balance in teaching and assessing all the teaching skills (listening, speaking, reading and writing; see, Section 1.3) and aim at focusing the speaking component of the English language (as discussed in Section 1.2.2, it is the most neglected skills taught and assessed). However, the teachers in this study believe the writing component of the language is important to be taught, practiced and assessed.

Despite the fact that SBA promotes multiple activities for the teachers to assessed their pupils' performances and that the teachers in this study held strong pedagogical beliefs about SBA as well as having some understanding of its underlying principles, they remained with some existing pedagogical beliefs on teaching and assessment practices (Section 6.3 to 6.5). The contextual factors (the knowledge and training of SBA; the examination system; scoring, recording and reporting of SBA; interference of other reform initiatives and; the monitoring of SBA) discussed in this study were the main reasons for the teachers to retain with existing pedagogical beliefs and practices about teaching and assessment. Thus, prevented their willingness and ability to implement SBA as recommended and suggested in the SBA documents. I provide an example how these contextual factors hindered the teachers' implementation process of SBA and affected the teachers' strong held beliefs about SBA. Liz commented that as far as she had noticed, there had not been any monitoring done on SBA, even after a few years of its implementation, nor was there any emphasis on doing SBA in the classroom even though the Education Department required the yearly result to be submitted - but no further action was taken when the results were not submitted. Even if there was monitoring or encouragement to conduct SBA, it was usually done through meetings in the school. But although there were 
problems with SBA, there was not much discussion even in meetings, as admitted by her head teacher (see, head teacher and officials comment how monitoring of SBA is conducted in Section 5.1.5).

This discussion illustrates that there is not much emphasis from school and local education authorities on teachers conducting SBA in the classroom because of the loose way it is monitored. Head teachers and officers may also think that simply conducting meetings to discuss the implementation of SBA is enough. In the absence of proper training in SBA, head teachers and officers may themselves not have the necessary knowledge and skills to monitor its implementation in the Malaysian primary classrooms.

Therefore, in making sense of the mandated SBA regardless the loose way it is being monitored the teachers in this study interpreted, altered, modified and implemented SBA using their pedagogical knowledge and beliefs and incorporating existing or prior teaching-learning and assessment practices, according to the needs of the Malaysian educational context. The overall findings of the study pointed to a limited uptake of SBA implemented in the Malaysian primary school system as it faced with major challenges. It is the reasons why the teachers in this study apply changes being imposed on them in ways which allow the curriculum to make sense in their teaching and learning context.

A study conducted by Rahman (2014) also found incongruence between teachers' practices and the expectations of the Malaysian primary school curriculum (the KSSR) where the teachers' teaching had focused and remained on examination preparation than on actual learning (or as suggested and recommended in the curriculum). She states:

Despite the fact that the curriculum focused on the development of students' ability to use the language appropriately, meaningfully and effectively, the teachers believed that learning meant providing as much facts and information (i.e. input) as possible and effective teaching was where students were able to remember that was being taught. There was no emphasis on whether students were able to achieve and perform the desired skills and apply them in their daily life. (p.169)

Her study revealed the reasons behind her findings included teachers did not fully understand the content of the curriculum and the cascade training used to inform the Malaysian primary school teachers about the change was ineffective. Therefore, it is not surprising that the teachers in this study could also alleviated from the recommended practices of SBA and retained with some of the existing teaching and assessment practices because of the way the SBA training was carried out and introduced.

The fact that teachers remained with existing pedagogical beliefs and practices in this study echoes Spillane's framework, the individual cognition element recognises that the development of new knowledge occurs through existing structures (e.g. teachers' existing knowledge and practices concerning teaching and learning). Spillane (2002) also emphasised that these structures need to be supported, or little may be achieved in terms of realising change (as discussed in Section 2.4.1). This also echoes Hayes (1995) suggestions, the teachers' existing beliefs or values which influence their practices are important to recognise in professional development programmes. Fullan and Steigebauer (1991) and Wedell (2003) also agree saying teachers experiencing change must have proper guidance, because they may not know what needs to be changed or how to go about changing it.

The reality for educational reform may not be implemented as intended is a phenomenon widely discussed in many existing studies (e.g. Harvey, 1999; Rahman, 2014; Al- Safawi 2014). The main evident reveals that the teachers' existing pedagogical beliefs and practices were not identified and confronted during the introduction of the change. This study may represent another example of a reform initiative which had failed to meet these needs. The evidences gathered in this study, show the importance to consider teachers' prior or existing beliefs about assessment and contextual factors to understand the motives behind the teachers' actual assessment practices and their attitude to assessment reforms. This could extend our current understanding of SBA and provides some implications to continuing research on English language teachers' beliefs about SBA in Asian context and elsewhere in general.

\section{Conclusions}

The participants involved in this study only represent a small number of primary school English language teachers (Liz, Chen and Dennis). The information elicited from these teachers may not represent the whole population of teachers in Malaysia. However, I am convinced that the information I gathered from these participants provides valuable information about the current situation with regards to the implementation. This study has provided insights into three English language teachers' pedagogical beliefs and their actual SBA practices. The study only focused on the teachers and what they do and why they do it, in terms of SBA. I suggest that for future research, the following could provide valuable insights with regards to SBA:

- This study used a qualitative methodology to uncover the reasons behind the teachers' practices, providing an in-depth discovery of what teachers do in terms of SBA being imposed on them. I suggest that this study can provide the basis for the design of a survey in which the practices and beliefs of a wider range of teachers can be studied. For example, a 
survey that focuses on the dimensions of teachers' pedagogical conceptions of effective feedback primarily focusing at primary school level or young learners; conceptions about assessment, their attitude towards educational reform (about assessment in particular) and their pedagogical beliefs about assessment (mainly a focus on classroom assessment) could be useful for curriculum reformers in considering the best way to support the SBA policy or to develop it in new directions.

- This study also took the initiative to interview one Ministry of Education officer in the curriculum unit, which provided very useful information. I suggest that interviewing policy makers and getting their ideas on what lies behind the change or behind any future changes, for that matter, would be equally insightful. This is because when education officials (the policy makers and those running the policy for them) and the teachers understand reasons for the change and its importance. Such understanding enables both parties to work towards the direction and aims of the change.

- This study has highlighted that since the introduction of SBA, parents influence the way the teachers in the study implemented SBA. A focus on parents regarding how they feel about SBA, what they believe about assessment and what it means for their children to be assessed could provide an understanding of what type of assessment parents prefer and how their preferred assessment can be aligned with the SBA initiatives. Literature has emphasised about the importance of parental involvement in education reforms (Comer and Haynes, 1991; Epstein, 1995) and to consider parents as 'partnership' in education (Dewey, 1916 cited in Shumow, 1997, p. 205). This is because parents seem to reject reforms that they do not understand and advocate a return to old practices for this reason (Cassanova, 1996). Literature also indicates that parents seem to accept education reforms when they understand and are consulted about them (Shumow, 1998). Shumow (1997) argued that little research had been conducted about parental beliefs with regards to schooling and learning although they are considered important stakeholders. He further stated that to include parents' participation in education decision-making their views about education (about assessment in the case of this study) should be considered.

- Finally, although this study represents only a small number of teachers, it outlines valuable directions of research on educational reform and the contextual factors influencing teachers strong held pedagogical beliefs about SBA and its practices (see, Section 7.2). Possible study could be undertaken about teachers' pedagogical beliefs about assessment and reflection on their identity, role and responsibilities on assessment practices. This could be an important step in changing teachers' existing pedagogical beliefs about assessment. By reflecting ones identity, roles and responsibilities could lead to teachers changing pedagogical beliefs and behaviour (Mihaela and Alina-Oana, 2015). Specifically could lead to a valuable discovery and ways that could change teachers' attitude toward existing pedagogical beliefs about teaching-assessment practices.

\section{References}

[1] Rahman, N.H. (2014). From curriculum reform to classroom practice: an evaluation of the English primary curriculum in Malaysia. [Doctoral Thesis]. University of York.

[2] Abdul Rahman, A. (1987). Curriculum Innovation in Malaysia: a case of KBSR. [Doctoral Thesis]. University of London Institute Education.

[3] Anderson, L. and Burns, R. (1989). Research in classrooms. Oxford: Pergamon.

[4] Bishop, A. Seah, W. T. and Chin, C 2003. Values in mathematics teaching-The hidden persuaders? In: A. BISHOP. M. A. CLEMENTS. C. KEITEL, J. KILPATRICK and F. K. S LEUNG, eds. Springer international handbooks of education: Vol. 10. Second international handbook of mathematics education. Dordrecht, The Netherlands: Kluwer. 717-765.

[5] Black, B.Y.P. Harrison, C. Lee, C. Marshall, B. and Wiliam, D. (2004). Working inside the black box: assessment for learning in the classroom. Phil Delta Kappan. 86(1), 8-21.

[6] Black, P. (2004). The nature and value of formative assessment for learning. Improving Schools [online]. 6(3), 7-22. Available from: http://journals.sagepub.com/doi/abs/10.1177/136548020300600304.

[7] Black, P. and Wiliam, D. (2003). In praise of education research: formative assessment. British Educational Journal. 29(5), $623-637$.

[8] Black, P. and Wiliam, D. (1998). Assessment and classroom learning. Assessment in Education. 5(5), pp.7-74.Black, P. and Wiliam, D. (2009). Developing the theory of formative assessment. Educational Assessment, Evaluation and Accountability. 21(1),5-31.

[9] Black, P. and Wiliam, D. (1998). Inside the black box: Raising standard through classroom assessment. London: GL Assessment.

[10] Borg, S. (2001). The research journal: a tool for promoting and understanding researcher development. Language Teaching Research. $5(2), 156-177$.

[11] Borg, S. 2003. Teacher cognition in language teaching: a review of research on what teachers think, know, believe, and do. Language Teaching. 36(2), 81-109.

[12] Borg, S. 2006. Teacher cognition in language education: Research and practice. London: Continuum.

[13] Cassanova, U. (1996). Parental involvement: a call for prudence. Educational Researcher. 25(8),.30-32. 
[14] Chan, Y.F. and Sidhu, G. (2012). School-Based Assessment among ESL teachers in Malaysian secondary schools. Journal Pendidikan, University Sains Malaysia [online]. 1(1), 1-18. Available from: http://education.usm.my/images/docs/MEDC/VOL9/full paper jurnal pendidikanusm edited.pdf.

[15] Christodoulou, D. (2014). Seven myths about education. 1st ed. Routledge Taylor and Francis Group.

[16] Christodoulou, D. (2016). Making good progress? The future of assessment for learning. 1st ed. Oxford, UK: Oxford University Press.

[17] Cormer, J. and Haynes, N. (1991). Parent involvement in schools: an ecological approach. Elementary School Journal. 91(1), $271-277$.

[18] Duncan, N. (2007). Feed-forward: improving students' use of tutors' comments. Assessment and Evaluation in Higher Education. 32(3), pp.271-283.

[19] Epstein, J. (1995). School, community and partnerships: caring for the children we share. Phi Delta Kappan. 76(1).701-712.

[20] Fullan, M. (2001). The new meaning of educational change. New York: Teacher College Press.

[21] Fullan, M.G. and Miles, M.B. (1992). Getting reform right: what works and what doesn't. Phil Delta Kappan. 75(1),.745-752.

[22] Fullan, M.G. and Steilgelbauer, S. (1991). The new meaning of educational change. 2nd ed. New York: Teachers' College Press.

[23] Harvey, S. (1999.) The impact of coaching in South African primary science. Journal for Education Development. 19(3), 191-205.

[24] Hayes, D. (1995). In-service teacher development: some basic principles. ELT Journal [online]. 49(1), 252-261. Available from: http://eltj.oxfordjournals.org/content/49/3/252.short.

[25] Kagan, D. (1992). Implications of research on teacher belief. Educational Psychologist. 27(1),.65-90.

[26] Lincoln, Y. and Guba, E. (1995). Naturalistic inquiry. Newbury Park, CA: Sage Publications.

[27] Maclellen, E. (2001). Assessment for learning: the differing perceptions of tutors and student. Assessment and Evaluation in Higher Education. 26(4), 307-318.

[28] Mansour, N. (2013). Consistencies and inconsistencies between science teachers' beliefs and practices. International Journal of Science Education. 35(7), 1230-1275.

[29] Merriam, S.B. (2002). Qualitative Research in Practice: examples for discussion and analysis.p.439. Available from: http://www.lavoisier.fr/livre/notice.asp?id=OLSWL6AAS6AOWG.

[30] Merriam, S.B. (2009). Qualitative research: a guide to design and implementation. 2nd ed. San Francisco, CA: The Jossey-Bass.

[31] Mihaela, V. and Alina-Oana, B. (2015. (When) teachers' pedagogical beliefs are Changing? Procedia - Social and Behavioral Sciences [online]. 180(November 2014), pp.1001-1006. Available from: http://www.sciencedirect.com/science/article/pii/S1877042815015372.

[32] Ministry of Education, M. (2010). Kurikulum standard sekolah rendah: Teacher's guide SK and SJK English language Year 3.

[33] Ministry of Education, M. (2011). English language curriculum for Malaysian primary schools Year 1: a teacher's guidebook. (M. Curriculum Division Development). Putrajaya: Ministry of Education Malaysia.

[34] Ministry of Education, M. (2012). Pentaksiran berasaskan sekolah soalan-soalan lazim: PBS tahu prestasi saya. Portal Rasmi Kementerian Pendidikan Malaysia [online], pp.1-22. Available from: http://www.moe.gov.my/index.php/my/soalan-lazim/52-soalan-lazim [Accessed November 17, 2016].

[35] Ministry of Education, M. (2003). Curriculum specifications English language Year 5..1-8.

[36] Ministry of Education, M. (2013). Kurikulum standard sekolah rendah: dokumen standard kurikulum dan pentaksiran Bahasa Inggeris SK Tahun 4. Putrajaya: Kementerian Pendidikan Malaysia.

[37] Ministry of Education, M. (2011). Primary school standard curriculum: English language Year 1 \& 2. 1st ed. Putrajaya: Kementerian Pendidikan Malaysia.

[38] Ministry of Education, M. (2012). Preliminary Report: Malaysia education blueprint 2013-2025. Putrajaya: Kementerian Pendidikan Malaysia.

[39] Ministry of Education, M. (1999). Surat Pekeliling Penyediaan rekod pengajaran dan pembelajaran. Kuala Lumpur, Malaysia: Kementerian Pendidikan Malaysia.

[40] Mohammed Al Sawafi, O.S. (2014). Investigating English teachers' beliefs and practices in relation to the continuous assessment reform in the Sultanate of Oman. [Doctoral Thesis]. University of Leeds.

[41] Nunan, D. (2004). Task-based language teaching. Cambridge, UK: Cambridge University Press.

[42] Omar, H. and Sinnasamy, P. 2009. Between the ideal and reality: teachers' perception of implementation of school-based oral assessment. The English Teacher. 38(1),13-29.

[43] Orafi, S.M.S. (2008). Investigating teachers' practices and beliefs in relation to curriculum innovation in English language teaching in Libya. Available from: http://etheses.whiterose.ac.uk/1485/.

[44] Pajares, M.F. (1992). Teachers' beliefs and educational research: cleaning up a messy construct. Review of Educational Research. 62(3), 307332.

[45] Philipp, R. A. (2007). Mathematics teachers' beliefs and affect. Handbook of research on mathematics teaching and learning. 1(1), $257-315$.

[46] Pike, M. (2002). Action research for English teaching: ideology, pedagogy and personal growth. Educational Action Research [online]. 10(1), pp.27-44. Available from: http://www.tandfonline.com/doi/abs/10.1080/09650790200200176.

[47] Raths, J. (2001). Teachers' beliefs and teaching beliefs what technologies are available to teacher educators for changing candidate. Early Childhood Research and Practices [online]. 3(1), pp.1-9. Available from: http://ecrp.uiuc.edu/v3n1/raths.html.

[48] Richardson, V. (1996). The role of attitudes and beliefs in learning to teach. New York: McMillan.

[49] Sadler, D.R. (1998). Formative Assessment: revisiting the territory. Assessment in Education: Principles, Policy \& Practice. 5(1), pp.77-84.

[50] Sardareh, S. and Mohd Saad, M.R. (2013). Malaysian primary school ESL teachers' questions during assessment for learning. English Language Teaching [online]. 6(8), 1-9. Available from: http://www.ccsenet.org/journal/index.php/elt/article/view/28726 [Accessed October 17, 2014].

[51] Sardereh, S. and Mohd Saad, M.R. (2012). A sociocultural perspective on assessment for learning: the case of a Malaysian primary school ESL context. Procedia - Social and Behavioral Sciences. 66(1),.343-353.

[52] Shumow, L. (1997). Parents ' educational beliefs: Implications for parent participation in school reforms. School Community Journal. 7(1), 205-218. 
[53] Shumow, L. (1998). Contributions of parent education to adult development. In: C. SMITH and T. POURCHOTS, eds. Adult learning and development and perspectives from education psychology. Hillside, NJ: Lawrence Erlbaum, 239-255.

[54] Sidhu, K.G. Chan, Y.F. and Mohamad. A. (2011). Teachers' knowledge and understanding of the Malaysian school-based oral English assessment. Malaysian Journal of Learning and Instruction. 8(1).93-115.

[55] Skilbeck, M. (1998). School-based curriculum development. In: A. HARGREAVES et al., eds. International handbook in educational change. Dordrecht, The Netherlands: Kluwer Acadmeic Publisher, pp. 121-144.

[56] Snape, D. and Spencer, L. (2003). The foundation of qualitative research. In: J. RITCHIE and J. LEWIS, eds. Qualitative research practice: A guide for social science students and researchers. London: Sage Publications Ltd, pp. 2-10.

[57] Spillane, J.P. Diamond, J. B. Burch, P. Hallett, T. Jita, L. and Zoltners, J. (2002). Managing in the Middle: school leaders and the enactment of accountability policy. Educational Policy. 16(5).731-762.

[58] Squires, M. (2013). Moving beyond the transmission of feedback: strategies to engage students. Teaching and Learning [online]. 1(1). Available from: http://digitalcommons.plattsburg.edu/commongood.

[59] Stipek, D.J. Givvin, K. B. Salmon, J. and Macgyvers, V. L. (2001). Teachers' beliefs and practices related to mathematics instruction. Teaching and Teacher Education [online]. 17(1), pp.213-226. Available from: http://www.sciencedirect.com/science/article/pii/S0742051X00000524.

[60] Tudor, I. (2001). The dynamics of language classroom. Cambridge: Cambridge University Press.

[61] Vygotsky, L. (1999). The problem of speech and thinking in Piaget's theory. In: R. W. RIEBER and A. S. CARTON, eds. The Collective Works of L.S Vygotsky. Plenum Press, New York: Springer US,. 53-91.

[62] Vygotsky, L.S. (1978). Interaction between learning and development. Mind and Society, pp.79-91.

[63] Walsham, G. (2009). Interpreting information systems in organizations interpreting information systems in organizations. Zurich, Switzerland: Global Text.

[64] Wedell, M. (2003). Giving TESOL change and chance: supporting key players in curriculum change process system.31(4),.439-456.

[65] Wedell, M. (2009). Planning for education change: putting people and their contexts first. London: Continuum International Publishing Group.

[66] Willis, J.E. (1995). A recursive, reflective instructional design model based on constructivist-interpretivist theory. Educational Technology. 35(6).5-23.

[67] Wotjas, O. (1998). Feedback? No just give us answers. Times Higher Education Supplement, 25 September [online]. Available from: http://www.timeshighereducation.co.uk/109162.article [Accessed November 26, 2016].

[68] Xu, L. (2012). The Role of teachers' beliefs in the language teaching-learning process. Theory and Practice in Language Studies. 2(7), 13971402.

[69] Zhang, F. and Liu, Y. (2014). A study of secondary teachers' beliefs in the context of secondary teachers' beliefs of curriculum reform in China. Language Teaching Research. 18(2),187-204.

[70] Zheng, H. (2009). A review of research on EFL pre-service teachers' beliefs and practices. Journal of Cambridge Studies. 4(1).73-81 